\title{
Mitochondrial mutation commonly associated with Leber's hereditary optic neuropathy observed in a patient with Wolfram syndrome (DIDMOAD)
}

\author{
D Pilz, O W J Quarrell, E W Jones
}

\begin{abstract}
DIDMOAD is usually considered an autosomal recessive condition, with wide phenotypic variation, but the possibility of mitochondrial mutations occurring in this condition has been considered. A 19 year old man presented with long standing diabetes mellitus, optic atrophy, and grand mal seizures. Further investigations showed unilateral sensorineural hearing loss and the most common mitochondrial DNA mutation associated with Leber's hereditary optic neuropathy, which was inherited from his mother. This suggests the DIDMOAD phenotype is a mitochondrial disorder in some cases and is likely to have a heterogeneous aetiology.
\end{abstract}

( $\mathcal{F}$ Med Genet 1994;31:328-330)

Wolfram and Wagner ${ }^{1}$ reported the combination of diabetes mellitus and optic atrophy in 1938. Subsequently, deafness and diabetes insipidus were noted to be frequently associated with the above, ${ }^{2}$ and the condition is known as Wolfram syndrome or by the acronym DIDMOAD syndrome (diabetes insipidus, diabetes mellitus, optic atrophy, and deafness). However, the acronym may be misleading, as some patients have additional problems, including dilatation of the urinary tract, $^{23}$ hypogonadism, ${ }^{23}$ retinal pigmentation, ${ }^{2}$ epilepsy, ${ }^{4}$ ataxia, ${ }^{4}$ and sideroblastic anaemia. $^{5}$

DIDMOAD syndrome is usually considered an autosomal recessive disorder ${ }^{6}$ (McKusick number 222300). Parental consanguinity has been noted and males and females have been described in equal numbers. However, there is an unusual phenotypic variability, even among sibs. This, together with the occurrence of features commonly seen in mitochondrial disorders, led Bundey $e t a l$ to suggest that DIDMOAD syndrome may be a mitochondrial disorder. They reported a patient with this condition, who had both morphological and biochemical abnormalities of his mitochondria; however no abnormalities of the mitochondrial DNA were detected.

We now report a patient with the DIDMOAD phenotype, who had a mitochondrial mutation commonly seen in Leber's hereditary optic neuropathy (LHON).

\section{Case report}

Our proband was a 19 year old man, who presented with a combination of diabetes mellitus, optic atrophy, and grand mal epilepsy. $\mathrm{He}$ is the son of non-consanguineous parents and has a healthy older brother. The extended family history is unremarkable.

At the age of 2 years he developed insulin dependent diabetes mellitus. His visual acuity was recorded as $6 / 9$ in both eyes at the age of 9 years. Apart from his diabetes mellitus he remained generally well until the age of 14 years when he developed tonic-clonic seizures, which now occur mainly at night and are controlled with sodium valproate. Electroencephalograms performed in 1989 and 1991 showed excessive background slow activity, but no frank epileptic discharges.

Six months after developing the seizures he complained of blurred vision in both eyes. $\mathrm{He}$ was under regular follow up by an ophthalmologist and was known to have mild myopia. His vision deteriorated over the next few months, but apart from a markedly reduced visual acuity (from $6 / 12$ to counting fingers on the right side and $6 / 5$ to $6 / 60$ on the left side within a year), other investigations, including a fluorescein angiogram and a cranial CT scan, were reported as normal. His symptoms persisted and a repeat CT scan was again normal, but visual evoked responses were absent in both eyes.

When re-examined four years after the onset of his visual disturbance, he was noted to have bilateral optic atrophy and large central scotomas. $\mathrm{He}$ is now registered as blind. A further cranial CT scan and an MRI scan were normal.

At this stage he was referred to the Genetic Department for consideration of the diagnosis of LHON. In view of the above history a diagnosis of DIDMOAD syndrome was also considered and an audiogram indicated unilateral sensorineural hearing loss in the high frequency range. He also had a water deprivation test which was normal. His islet cell antibodies were negative and HLA typing showed only one antigen commonly found in autoimmune diabetes mellitus, DR3. Retrospectively his fluorescein angiogram, which focused on diabetic retinopathy at the time, suggests the presence of some tortuous peripapillary vessels, which are an early and transient sign in LHON.

DNA analysis using amplification of the relevant part of mitochondrial DNA from

\footnotetext{
Received 1 September 1993 Revised version accepted for publication 11 November
1993

Hospital, Centre for

Human Genetics, 11

D Pilz

Infirmary, Armthorpe

E W Jones
} 
Incidence of symptoms in DIDMOAD syndrome and our patient

\begin{tabular}{|c|c|c|c|c|c|}
\hline & \multicolumn{2}{|c|}{ Cremers et al ${ }^{2}$ ( 88 cases) } & \multicolumn{2}{|c|}{ Dreyer et al (98 cases) } & \multirow[b]{2}{*}{ Present patient } \\
\hline & Present $(\%)$ & Not specified (\%) & Present $(\%)$ & Mean age (y) & \\
\hline $\begin{array}{l}\text { Diabetes mellitus } \\
\text { Optic atrophy } \\
\text { Abnormal audiogram } \\
\text { Diabetes insipidus } \\
\text { Abnormal EEG } \\
\text { Epilepsy }\end{array}$ & $\begin{array}{r}98 \\
98 \\
39 \\
32 \\
16 \\
5\end{array}$ & $\begin{array}{l}- \\
\overline{41} \\
39 \\
59\end{array}$ & $\begin{array}{l}100 \\
98 \\
48 \\
35 \\
\text { Not discussed }\end{array}$ & $\begin{array}{r}7(2-20) \\
11(4-22) \\
16(3-32) \\
14(1-29)\end{array}$ & $\begin{array}{l}+ \\
+ \\
+ \\
+ \\
+\end{array}$ \\
\hline
\end{tabular}

blood and digestion with $S f a \mathrm{NI}$ and $M a e \mathrm{II}^{8}$ showed the presence of the mitochondrial $11778 \mathrm{G}$ to $\mathrm{A}$ point mutation. This was also present in his mother.

\section{Discussion}

This patient with diabetes mellitus, optic atrophy, sensorineural deafness, and epilepsy has the clinical phenotype of DIDMOAD syndrome and the absence of diabetes insipidus does not preclude the diagnosis (table). There are several possible explanations for the occurrence of the DIDMOAD phenotype in association with a mitochondrial point mutation commonly seen in LHON.

We think it is unlikely that the phenotype results solely from the mitochondrial mutation. The 11778 mutation has so far mainly been reported in families with optic atrophy alone. Cardiac pre-excitation syndromes ${ }^{10}$ and a multiple sclerosis-like illness in women ${ }^{11}$ have been reported with this mutation but, in general, extraocular manifestations are rare. These were reviewed by Newman et $a l^{12}$ and most appear to be fortuitous. It is possible that this is the case in our patient.

Mitochondrial mutations as a cause for diabetes mellitus are being increasingly discussed. Balinger $e t a l^{13}$ pointed out that studies have shown increased maternal inheritance in patients with onset of diabetes mellitus at 25 years or older. They report a family showing maternal transmission of diabetes mellitus and deafness linked to a $10.4 \mathrm{~kb}$ deletion of the $\mathrm{mt}$ DNA in the affected members. Similarly, Reardon $e t a^{14}$ reported a point mutation of the mtDNA in a family with diabetes mellitus and deafness.

Wallace et $a l^{15}$ have discussed environmental stresses as a possible explanation for the variable expression of LHON. It is possible that our patient has autoimmune diabetes, which in combination with the LHON mutation accounts for the extended phenotype. The optic neuropathy seen in this patient was typical of LHON. The absence of islet cell antibodies 17 years after diagnosis and the presence of the HLA DR3 antigen does not allow us to diagnose or exclude autoimmune diabetes mellitus. In their review, Newman et $a l^{12}$ reported a family with multiple affected members; onset of visual problems was in their 30s, with the exception of a 9 year old girl whose early visual loss was associated with undiagnosed diabetes mellitus.

Finally, it is possible that the phenotype results from the combination of the 11778 mutation with an, as yet, undetected mutation elsewhere on the mitchondrial genome, or with a mutation of the nuclear genome in homo- or heterozygous form. With regard to the former, we are aware of a patient described as having the features of DIDMOAD in whom a $7.6 \mathrm{~kb}$ deletion of the mitochondrial genome was found. ${ }^{1617}$ The features seen in that patient included diabetes mellitus, optic atrophy, retinitis pigmentosa, sensorineural deafness, and cerebellar ataxia, and also external ophthalmoplegia, extrapyramidal symptoms, mental retardation, and brittle hair, which are not normally associated with DIDMOAD but are well recognised in mitochondrial encephalomyopathy, which may be a better diagnostic label. The hypothesis of the combination of a mitochondrial mutation with a nuclear mutation has been postulated in some conditions. Jaber et $a l^{18}$ discussed the possible combination of an autosomal recessive mutation with a mitochondrial mutation in a large pedigree with sensorineural deafness. The inheritance of LHON is also subject to controversy in view of the excess of affected males, which cannot be explained by the mitochondrial mutation alone. This has led some authors ${ }^{1920}$ to consider the possibility that LHON results from the combination of a mitochondrial mutation and an $\mathrm{X}$ linked visual loss susceptibility gene. The evidence for this remains inconclusive. ${ }^{2122}$

In conclusion, we suggest that mitochondrial mutations are sought in patients with the DIDMOAD phenotype and think that the aetiology of DIDMOAD should be considered as heterogeneous.

Since submission of this manuscript, $\mathrm{Bu}$ and Rotter $^{23}$ have suggested that DIDMOAD may result from mutations in either the mitochondrial genome or nuclear genome and that, in the latter case, the nuclear defect interferes with mitochondrial function. Their hypothesis supports the conclusions of this case report.

We wish to thank Mr S Govan and $\mathrm{Mr} M$ Brockington in Professor A Harding's laboratory for performing the DNA analysis; Professor Harding, Dr S Bundey, and Dr R Trenbath for their helpful comments; Mr I Strachan for referring the patient; and Mrs V Thompson for typing the manuscript.

1 Wolfram DJ, Wagner HP. Diabetes mellitus and simple optic atrophy amongst siblings. Mayo Clin Proc 1938;13:715-18.

2 Cremers CWRJ, Vijdeveld PGAB, Pinkers AJLG. Juvenile diabetes mellitus, optic atrophy, hearing loss, diabetes insipidus, atonia of the urinary tract and bladder, and (Wolfram synrome) Scand Suppl 1977;264:3-16.

3 Anonymous. DIDMOAD (Wolfram) syndrome. Editorial. Lancet 1986;i:1075-6.

4 Kinsey BT, Firth RGF. The Wolfram syndrome: a primary degenerative disorder with lethal potential. Irish Med $f$ degenerative disor.

5 Borgna-Pignatti C, Marradi P, Pinelli L, Monetti N, Patrini C. Thiamine responsive anaemia in DIDMOAD synC. Thiamine responsive anaemia
drome. $\mathcal{F}$ Pediatr $1989 ; 114: 405-10$.

6 Fraser FC, Gunn T. Diabetes mellitus, diabetes insipidus and optic atrophy: an autosomal recessive syndrome? $\mathcal{f}$

7 Bundey S, Poulton K, Whitwell H, Curtis E, Brown IAR 
Fielder AR. Mitochondrial abnormalities in the DID MOAD syndrome. F Inher Metab Dis 1992;15:B15-B19. 8 Harding AE. Leber's hereditary optic neuropathy. In: D Mauro S, Schapira AHV, eds, Mitochondrial diseases.
Mard

9 Dreyer M, Ruediger HW, Bujara K, et al. The syndrome of diabetes insipidus, diabetes mellitus, optic atrophy, deafness, and other abnormalities (DIDMOAD syndrome) Klin Wochenschr 1982;60:471-5.

10 Nikoskelainen E, Wanne O, Dahl M. Pre-excitation syndrome and Leber's hereditary optic neuroretinopathy. Lancet 1985; i:696.

11 Harding AE, Sweeney MG, Miller DH, et al. Occurrence of a multiple sclerosis-like illness in women who have Leber's hereditary optic neuropathy mitochondrial DNA mutation. Brain 1992;115:979-89.

12 Newman NJ, Lott MT, Wallace DC. The clinical characteristics of pedigrees of Leber's hereditary optic neuropathy with the 11778 mutation. Am $f$ Ophthalmol 1991;111:750-62.

13 Ballinger SW, Shoffner JM, Hedaya EV, et al. Maternally transmitted diabetes and deafness associated with a $10.4 \mathrm{~kb}$ mitochondrial DNA deletion. Nature Genet 1092;1:11-15.

14 Reardon W, Ross RJM, Sweeney MG, et al. Diabetes mellitus associated with a pathogenetic point mutation in mellitus associated with a pathogenetic point m

15 Wallace DC, Singh G, Lott MT, et al. Mitochondrial DNA mutation associated with Leber's hereditary optic neuropathy. Science 1988;242:1427-30.
16 Munnich A, Rustin P, Roetig A, et al. Clinical aspects of mitochondrial disorders. F Inher Metab Dis 1992;15:448-

17 Roetig A, Cornier V, Chatelain $\mathrm{P}$, et al. Deletion of the mitochondrial DNA in a case of early onset diabetes mitochondrial DNA in a case of early onset diabetes
mellitus, optic atrophy and deafness. $₹$ Clin Invest 1993;91:1095-8.

18 Jaber $\mathrm{L}$, Shohat $\mathrm{M}, \mathrm{Bu} \mathrm{X}$, et al. Sensorineural deafness inherited as a tissue specific mitochondrial disorder. $\mathcal{f}$ Med Genet 1992;29:86-90

$19 \mathrm{Bu} \mathrm{X}$, Rotter JI. X-chromosome-linked and mitochondrial gene control of Leber's optic neuropathy. Evidence from segregation analysis for dependence on $\mathrm{X}$ chromosome inactivation. Proc Natl Acad Sci USA 1991;88:8198-202. 20 Vilkki J, Ott J, Savontaus M-L, Aula P, Nikoskelainen EK. Optic atrophy in Leber hereditary optic neuroretinopathy is probably determined by an X-chromosomal gene closely linked to DXS7. Am F Hum Genet 1991;48:486-91.

21 Sweeney MG, Davis MB, Lashwood A, Brockington M Toscano A, Harding A. Evidence against an X-linked locus close to DXS7 determining visual loss susceptibility in British and Italian families with Leber hereditary optic neuropathy. Am f Hum Genet 1992;51:741-8.

22 Juvonen V, Vilkki J, Aula P, Nikoskelainen E, Savontaus ML. Re-evaluation of the linkage of an optic atrophy ML. Re-evaluation of the linkage of an optic atrophy
susceptibility gene to X-chromosomal markers in Finnish susceptibility gene to $X$-chromosomal markers in Finnish families with Leber hereditary optic neuro
(LHON). Am f Hum Genet 1992;53:289-92.

$23 \mathrm{Bu} \mathrm{X}$, Rotter JI. Wolfram syndrome: a mitochondrialmediated disorder? Lancet 1993;342:598-600. 